\title{
All-trans Retinoic Acid Induces Expression and Secretion of Carboxypeptidase D in THP-1 Cells
}

\author{
Hang Thi Thu Nguyen* and Jae Young Kim ${ }^{\dagger ; * *}$ \\ Department of Life Science, Gachon University, Seongnam, Kyeonggi-Do 13120, Korea
}

\begin{abstract}
Carboxypeptidase D (CPD) is a zinc-dependent protease, which is highly expressed in macrophages, and is thought to participate in inflammatory processes. In the present study, we investigated the possible regulatory effect of all-trans retinoic acid (ATRA), which is an active form of vitamin A and plays a critical regulatory role in both the innate and adaptive immunity, on CPD expression and secretion in human monocytic THP-1 cells. CPD mRNA expression first increased, from a concentration as low as $10 \mathrm{nM}$ ATRA to a maximum level of expression, at $1 \mu \mathrm{M}$. ATRA enhanced intracellular CPD expression in a time- and concentration-dependent manner but did not affect cell surface CPD expression. Interestingly, 9-cis-RA did not affect CPD expression. Additionally, an experiment with RAR/RXR selective agonist or antagonists demonstrated that ATRA-induced enhancement of CPD expression was RAR/RXR dependent. ATRA also enhanced CPD secretion from THP-1 cells; however, this enhancement was RAR/RXR-independent. The anti-inflammatory agent dexamethasone reversed ATRA-induced enhancement of CPD expression and secretion. Our results suggest ATRA exerts regulatory effects on expression and secretion of CPD in human monocytes, and ATRA-induced CPD secretion may be associated with inflammatory response.
\end{abstract}

Key Words: All-trans retinoic acid, Carboxypeptidase D, THP-1, Monocytes, Vitamin A, Secretion, Inflammation

\section{INTRODUCTION}

All-trans retinoic acid (ATRA), a physiologically active form of vitamin A, plays a crucial role in embryonic development and cell fate determination (Niederreither and Dolle, 2008). In addition, ATRA plays an important regulatory role in both the innate and adaptive immunity (Kim, 2018). ATRA shapes early intestinal immune responses by promoting interleukin (IL)-22 synthesis by $\gamma \delta$ T cells and innate lymphoid cells (Mielke et al., 2013) and regulates dendritic cell differentiation (Klebanoff et al., 2013). ATRA controls gut homing of effector T cells, survival and effector func- tions of $\mathrm{CD}^{+} \mathrm{T}$ cells, and immune responses of Th17 cells (Iwata et al., 2004; Hall et al., 2011; DePaolo et al., 2011). Moreover, ATRA suppresses IgE synthesis and secretion (Scheffel et al., 2005), and induces the differentiation of regulatory B cells (Eriksen et al., 2015). ATRA is able to induce and promote the development and function of inducible regulatory T cells (Elias et al., 2008). ATRA mediates conversion of monocyte-derived macrophages into tissueresident macrophages (Gundra et al., 2017). ATRA inhibits the production of pro-inflammatory mediators, such as tumor necrosis factor (TNF)- $\alpha$, nitric oxide, and IL-12 in macrophages (Mehta et al., 1994; Kang et al., 2000; Wang et al., 2007). In contrast, ATRA enhances production of IL-10 in

Received: October 21, 2020 / Revised: December 12, 2020 / Accepted: December 14, 2020

* Graduate student, ${ }^{* *}$ Professor.

${ }^{\dagger}$ Corresponding author: Jae Young Kim. Department of Life Science, Gachon University, Seongnam, Kyeonggi-Do 13120, Korea. Tel: +82-31-750-4762, Fax:+82-31-750-5389, e-mail: jykim85@gachon.ac.kr

(C) The Korean Society for Biomedical Laboratory Sciences. All rights reserved.

(C) This is an Open Access article distributed under the terms of the Creative Commons Attribution Non-Commercial License (http://creativecommons.org/licenses/by-nc/3.0/) which permits unrestricted non-commercial use, distribution, and reproduction in any medium, provided the original work is properly cited. 
THP-1 (Wang et al., 2007) and contributes to murine M2 macrophage polarization synergistically with transforming growth factor (TGF)- $\beta$, prostaglandin E2, and IL-4 (Ho et al., 2016), suggesting an immune modulatory effect of ATRA on macrophages.

Proteases functions in various biological processes, such as cell growth, death, migration, and morphogenesis and protein catabolism and activation of coagulation. Proteases also play a critical regulatory role in immune system; they are involved in complement activation (Sim and Laich, 2000), antigenic peptide processing (Manoury, 2013), the activation or inactivation of immune mediators (Marshall et al., 2017). For instance, innate immune cells, such as monocytes/macrophages and neutrophils, contribute to inflammation during the initial phase of infection by secreting metalloproteinases, which cleave cytokines or chemokines, thereby activating or inactivating them (Parks et al., 2004).

Carboxypeptidase D (CPD) is a zinc-dependent protease, which specifically cleaves $\mathrm{C}$-terminal arginine or lysine. CPD is broadly expressed in mammalian tissues and especially high in macrophages (Skidgel and Erdos, 1998). CPD is primarily found in the trans-Golgi network, where it participates in protein processing in the constitutive secretory pathway (Varlamov and Fricker, 1998). However, CPD is also found to some extent on the plasma membrane, where it can cleave extracellular substrates (Varlamov et al., 1999; Hadkar and Skidgel, 2001; Kalinina et al., 2002). By re- moving the Cterminal arginine or lysine residues of proteins and polypeptide, CPD is suggested to participate in inflammatory processes; CPD mRNA and protein expression was markedly increased in murine macrophages following treatment with LPS and interferon (IFN)- $\gamma$ (Hadkar and Skidgel, 2001).

Despite its high expression in macrophages, no studies have investigated the possible regulatory effects of ATRA on CPD expression of human macrophages. The present study investigated the effect of ATRA on CPD expression and secretion in human monocyte THP-1 cells.

\section{MATERIALS AND METHODS}

\section{Reagents and chemicals}

ATRA, RAR $\alpha$ agonist BMS753, RXR $\alpha$ agonist LG-
100268, RAR $\alpha$ antagonist BMS195614, 9-cis-retinoic acid (9cis-RA), and dexamethasone were obtained from SigmaAldrich (St. Louis, MO, USA). RXR $\alpha$ antagonist UVI3003, anti- $\beta$-actin antibody, and secondary antibodies for western blot were purchased from Santa Cruz Biotechnology (Dallas, TX, USA). RPMI-1640 medium for cell culture was obtained from Welgene Inc. (Gyongsan, Korea). Fetal bovine serum (FBS) was purchased from Invitrogen (Gibco BRL, MD, USA).

ATRA was prepared as a $20 \mathrm{mM}$ stock in dimethyl sulfoxide (DMSO) and stored at $-20{ }^{\circ} \mathrm{C}$ before being diluted to the desired concentration in medium in each experiment. Purified anti-CPD antibody (ab184960) used in flow cytometric analysis was purchased from Abcam (Cambridge, MA, USA).

\section{Cell culture and treatment}

The human monocytic cell line THP-1 was obtained from Korean cell line bank. THP-1 cells were cultured in RPMI-1640 supplemented with 10\% heat-inactivated FBS, $1 \%$ antibiotic-antimycotic, $10 \mathrm{mM}$ HEPES, and $50 \mu \mathrm{M} \beta$ mercaptoethanol (Invitrogen). Cells were maintained at $37^{\circ} \mathrm{C}$ in a $5 \% \mathrm{CO}_{2}$ humidified incubator. Around 6 to $12 \mathrm{~h}$ before treatment, cells were seeded into T25 flasks and cultured in RPMI media without FBS

To determine agonist effects, cells were treated with agonist for $6 \mathrm{~h}$. Additionally, to assess the effects of ATRA antagonists, cells were pre-incubated with $1 \mu \mathrm{M}$ RAR $\alpha$ or $\mathrm{RXR} \alpha$ antagonist for $2 \mathrm{~h}$ and then with $1 \mu \mathrm{M}$ ATRA for $6 \mathrm{~h}$.

\section{Quantitative real-time PCR (qRT-PCR)}

To analyze the expression of $C P D$ in mRNA level, $10^{6}$ cells were treated with various concentration of ATRA or with $1 \mu \mathrm{M}$ ATRA and incubate at different times. Then, total mRNA was isolated and analyzed by qRT-PCR. The extraction of total RNA was performed using Qiagen RNeasy mini kit (Qiagen, Seoul, Korea). RNA concentrations were determined with a SD2000 micro spectrophotometer (Bioprince, Atlanta, GA, USA). cDNA was synthesized from $2 \mu \mathrm{g}$ of total RNA using MMLV reverse transcriptase (Bioprince) and an oligo dT primer (Bioprince) at $65^{\circ} \mathrm{C}$ for $1 \mathrm{~h}$.

qRT-PCR was performed on a iQ5 Multicolor Real-Time 
PCR Detection System (Bio-Rad, Hercules, CA, USA) using the iQ SYBR Green Supermix (Bio-Rad). The sequences of the specific primers were as follows: CPD 5'-ccaccaccatttccctgata-3', 5'-ccaaggaataaagccgggta-3'; and $\beta$-actin 5'-caccattggcaatgagcggttc-3', 5'-aggtctttgcggatgtccacgt-3'. Normalization was performed using the human $\beta$-actin gene as an endogenous control. For each sample, the relative abundance of target mRNA was calculated from the cycle threshold $(\mathrm{Ct})$ values for the target and endogenous reference gene $\beta$-actin.

\section{Flow cytometric analysis}

Flow cytometric analysis was performed to check the expression of intracellular and cell surface CPD expression in different treatment conditions. For determining surface expression, $10^{6}$ cells were incubated with $1 \mu \mathrm{M}$ ATRA for $48 \mathrm{~h}$. Then, cells were collected and incubated with purified anti-CPD antibody (ab184960) for $30 \mathrm{~min}$ at $4{ }^{\circ} \mathrm{C}$. After washing twice with phosphate buffered saline (PBS), the cells were incubated with the phycoerythrin-conjugated secondary antibody for $30 \mathrm{~min}$ at $4{ }^{\circ} \mathrm{C}$. After washing, cells were resuspended in PBS, and analyzed on a Cytomics FC500 MLP (Beckman Coulter Inc., Fullerton, CA, USA).

To determine intracellular CPD expression, cells were incubated with $4 \%$ formaldehyde fixation solution for $30 \mathrm{~min}$ at room temperature and then permeabilized with $0.1 \%$ Triton X-100 in PBS for 30 min. Following procedures are the same as those for detection of surface CPD expression by flow cytometry.

\section{Western blot analysis}

Cells were lysed with Triton X-100 lysis buffer (Santa Cruz Biotechnology). The supernatants from whole cell lysates were collected by centrifugation at $14,000 \times g$ for $15 \mathrm{~min}$. Cell lysate protein concentrations were measured using a Qubit Fluorometer (Invitrogen). Ten microgram of total protein was subjected to $10 \%$ sodium dodecyl sulfatepolyacrylamide gel electrophoresis and blotted onto a polyvinylidene difluoride membrane (Millipore Corp., Billerica, MA, USA). Membranes were then blocked with 5\% bovine serum albumin in $1 \times$ tris-buffered saline $(2.68 \mathrm{mM} \mathrm{KCl}$, $137 \mathrm{mM} \mathrm{NaCl}, 25 \mathrm{mM}$ Tris-HCl, and $0.05 \%$ Tween 20 ).
Subsequently, the membrane was probed with an anti-CPD (ab153874; Abcam) or anti- $\beta$-actin antibody (sc-1616). Proteins of interest were detected with HRP-conjugated goat anti-rabbit IgG antibody (sc-2055) or donkey anti-goat IgG antibody (sc-2020) and visualized with ECL Solution from GenDEPOT (Barker, TX, USA) using the ChemiDoc MP system (Bio-Rad) according to the provided protocol. $\beta$ actin was used as internal control.

To measure the secreted CPD proteins, the culture supernatants were collected by centrifugation at $180 \times g$ for 5 min and then concentrated by using Amicon Ultra-15 centrifugal filter (Millipore Corp.) at 4,000 $\times g$ for $30 \mathrm{~min}$ at $4{ }^{\circ} \mathrm{C}$. Thus, concentrated protein samples (32 times) were recovered and were subjected to western blot analysis.

\section{Statistical analysis}

Data were analyzed by one-way analysis of variance (ANOVA) followed by post hoc comparison with either the Tukey HSD (honestly significant difference test) for groups of data with equal variances or the Games-Howell test in one-way ANOVA with unequal variances using SPSS 12.0 for Windows. Values are expressed as mean \pm standard deviation (SD). Statistical significance was defined as $P<$ 0.05 .

\section{RESULTS}

\section{ATRA, but not 9-cis-RA, enhances CPD expression in THP-1 cells}

We examined effect of ATRA on CPD expression in THP-1 cells by qRT-PCR analysis. As shown in Fig. 1A, CPD mRNA expression first increased, from a concentration as low as $10 \mathrm{nM}$ ATRA to a maximum level of expression (approximately seven folds higher than that in the DMSOtreated control), at $1 \mu \mathrm{M}$ ATRA, and decreased thereafter. CPD mRNA expression sharply increased $6 \mathrm{~h}$ after $1 \mu \mathrm{M}$ ATRA treatment and gradually decreased thereafter; however, the expression of CPD mRNA at $48 \mathrm{~h}$ was still statistically higher than that in the DMSO-treated control (Fig. 1B). CPD protein expression levels, as determined by western blotting, were also enhanced (by approximately two folds) upon treatment with $1 \mu \mathrm{M}$ ATRA (Fig. 1C). Because CPD is known 
(A)

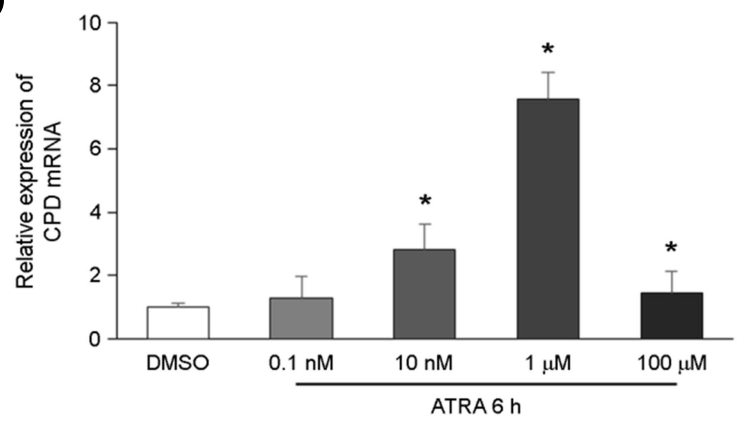

C
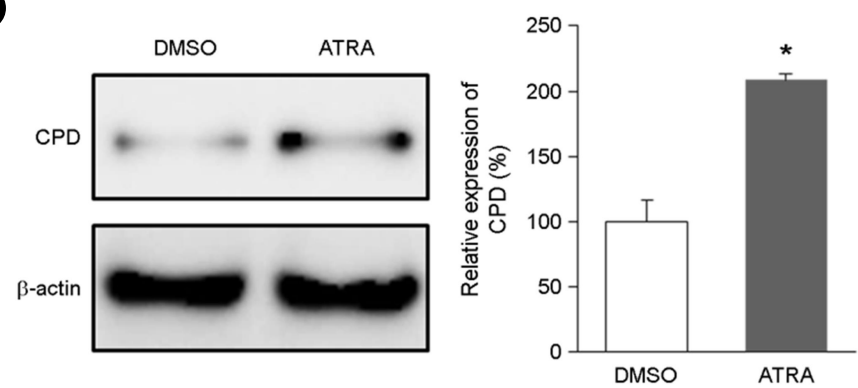

B

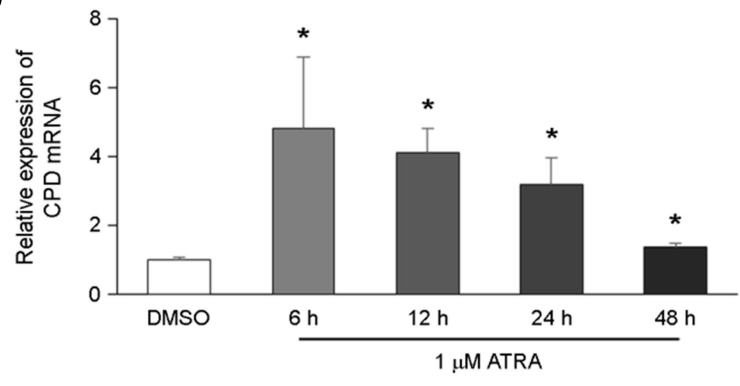

D

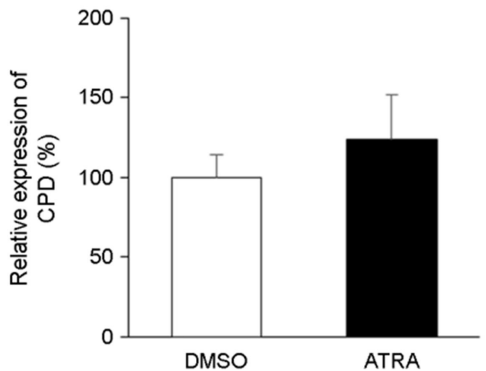

E

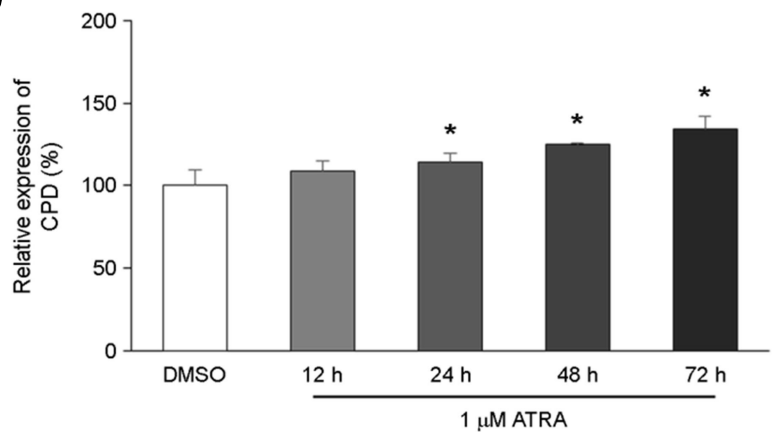

-

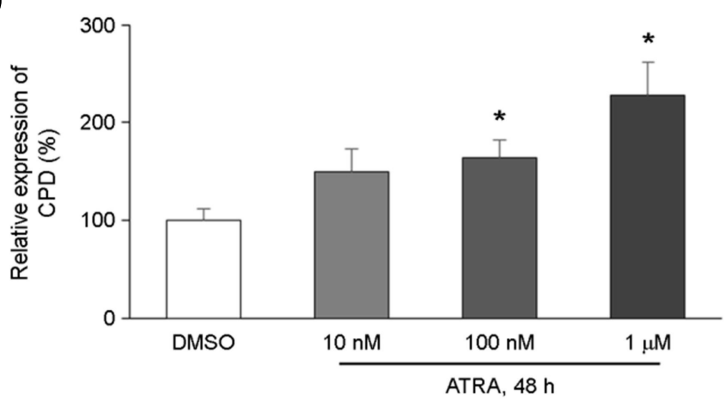

Fig. 1. ATRA upregulates CPD mRNA and intracellular protein expression but does not affect cell surface CPD protein expression in THP-1 cells. (A) THP-1 cells were treated with various concentrations of ATRA for $6 \mathrm{~h}$. (B) THP-1 cells were treated with $1 \mu$ M ATRA for various time periods, as indicated above. (C) CPD mRNA expression was examined by qRT-PCR. Cells were treated with $1 \mu \mathrm{M}$ ATRA for $48 \mathrm{~h}$. CPD protein levels were analyzed by western blotting, and densitometric analysis of CPD bands was performed using a ChemiDoc MP System. (D) Cells were treated with $1 \mu \mathrm{M}$ ATRA for $48 \mathrm{~h}$. Cell surface CPD expression was analyzed by flow cytometry. (E) THP-1 cells were treated with $1 \mu \mathrm{M}$ ATRA for various time periods or $(\mathrm{F})$ treated with various concentrations of ATRA, as indicated above, for $48 \mathrm{~h}$. (E and F) Intracellular CPD expression was measured by flow cytometry. Bar graphs present data as mean of relative expression $\pm \mathrm{SD}$. $* P<0.05$ vs. DMSO.

to be expressed on both the intracellular compartments and cell surfaces (Garcia-Pardo et al., 2017), CPD expression was also analyzed by flow cytometry. Intracellular CPD expression gradually increased over time (Fig. 1E) and was enhanced in an ATRA dose-dependent manner (Fig. 1F); however, cell surface CPD expression was not significantly affected by ATRA treatment (Fig. 1D).

9-cis-RA is the second most abundant retinoid in the human body and can bind and activate both RAR and RXR, while ATRA selectively binds RAR only (Bastien and Rochette-Egly, 2004). To determine whether ATRA and 9cis-RA exert a similar regulatory effect on CPD expression, we examined the effect of 9-cis-RA on CPD expression in THP-1 cells. As shown in Fig. 2A, 9-cis-RA did not affect CPD mRNA expression in THP-1 cells. Protein expression, as determined by western blotting, was also not affected by 
9-cis-RA treatment (Fig. 2B).

\section{ATRA-induced CPD expression depends on RAR/RXR pathway}

Since multiple biological functions of ATRA are mediated by the RAR/RXR pathway (Tsai and O'Malley, 1994), we wanted to confirm whether ATRA exerts its effect on CPD expression via this classical pathway. To this end, we used selective RAR- $\alpha /$ RXR- $\alpha$ agonists and antagonists and found that $10 \mu \mathrm{M}$ of the RAR agonist alone increases CPD protein expression. Moreover, combined treatment with $1 \mu \mathrm{M}$ RAR agonist and $1 \mu \mathrm{M}$ RXR agonist induced CPD expression comparable to that induced by $1 \mu \mathrm{M}$ ATRA (Fig. 3A). Additionally, treatment with $10 \mu \mathrm{M}$ RAR antagonist alone suppressed ATRA-induced CPD expression, but treatment with $10 \mu \mathrm{M}$ RXR antagonist alone did not (Fig. 3B). Combined treatment with $1 \mu \mathrm{M}$ RAR antagonist and $1 \mu \mathrm{M}$ RXR antagonist completely reversed the induction of CPD expression by ATRA (Fig. 3B)

\section{ATRA-induced CPD secretion depends on incubation time and ATRA concentration, but does not depend on RAR/RXR}

Since CPD is located in the secretory pathway (Varlamov
A

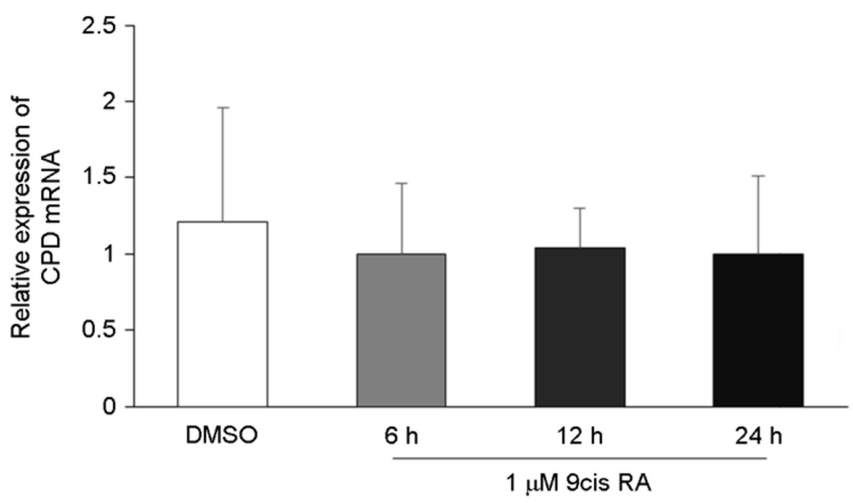

B

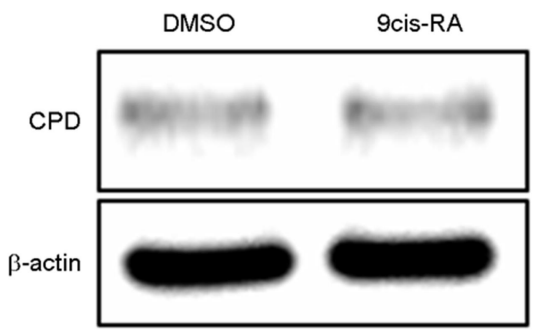

Fig. 2. 9-cis-RA does not affect CPD expression in THP-1 cells. (A) THP-1 cells were treated with $1 \mu \mathrm{M}$ 9-cis-RA for various time periods Expression of CPD mRNA was examined by qRT-PCR and was normalized to that of $\beta$-actin mRNA. Data are presented as mean of relative mRNA expression \pm SD. (B) Cells were treated with $1 \mu \mathrm{M}$ 9-cis-RA for $48 \mathrm{~h}$, and CPD protein levels were examined by western blotting.

A

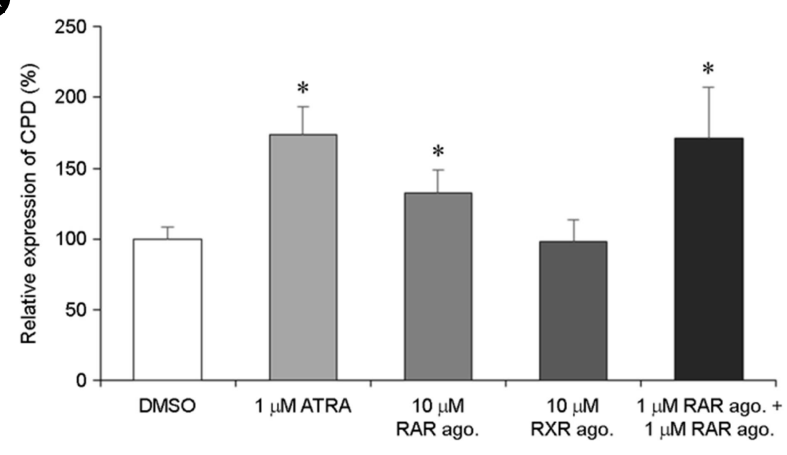

B

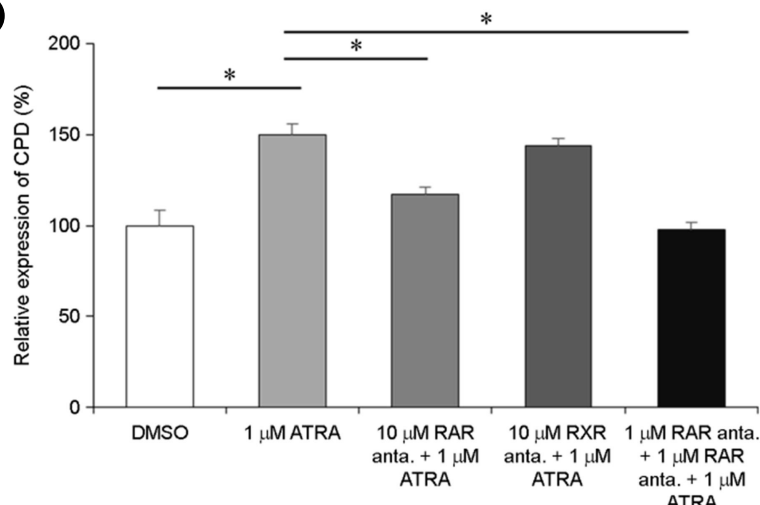

Fig. 3. ATRA enhances CPD expression through the RAR/RXR pathway. (A) THP-1 cells were incubated with $10 \mu M$ RAR agonist or RXR agonist alone or a combination of $1 \mu \mathrm{M}$ RAR agonist and $1 \mu \mathrm{M}$ RXR agonist. (B) Cells were pretreated with $10 \mu \mathrm{M}$ RAR or RXR antagonist alone, or a combination of $1 \mu \mathrm{M}$ RAR/RXR antagonists for $2 \mathrm{~h}$, followed by $1 \mu \mathrm{M}$ ATRA treatment. To measure intracellular CPD protein expression, after $48 \mathrm{~h}$ of incubation, cells were fixed, permeabilized, and analyzed by flow cytometry. Data are presented as mean of relative expression \pm SD. ${ }^{*} P<0.05$ vs. DMSO. 
and Fricker, 1998), we wanted to investigate the possibility of CPD secretion by THP-1 cells. To this end, THP-1 cells were treated with $1 \mu \mathrm{M}$ ATRA for $48 \mathrm{~h}$ and the culture supernatants were collected, concentrated by filtration, and subjected to western blotting (Fig. 4A). Secreted CPD levels were markedly increased by more than six folds upon ATRA treatment (Fig. 4B). After treatment with $1 \mu \mathrm{M}$ ATRA, secreted CPD levels sharply increased at $24 \mathrm{~h}$, reaching approximately $800 \%$ of the control level at $48 \mathrm{~h}$ and slightly decreasing thereafter (Fig. 4C and D). Secreted CPD levels were markedly increased by $100 \mathrm{nM}$ ATRA treatment, with a maximum increase of $2200 \%$ at $1 \mu \mathrm{M}$ ATRA (Fig. 4E and F).

To determine whether ATRA-induced CPD secretion is
A

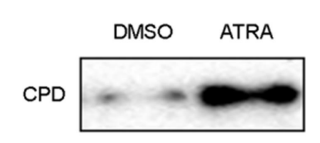

B

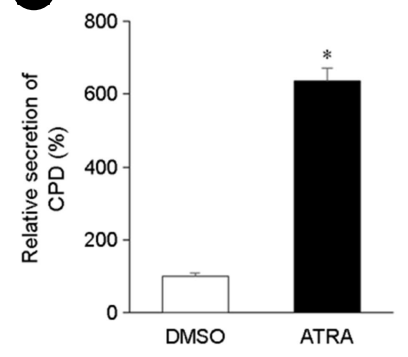

C

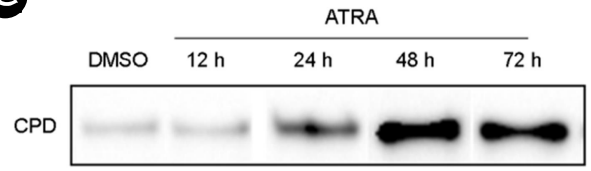

(D)

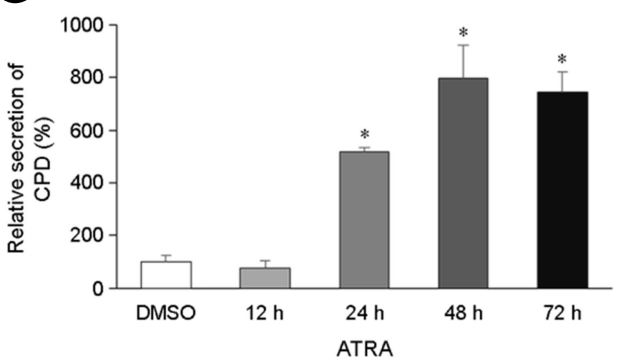

E

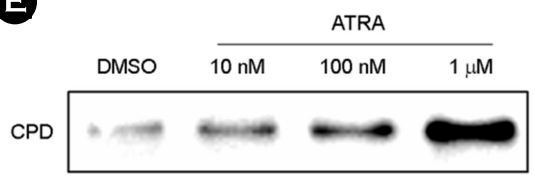

F

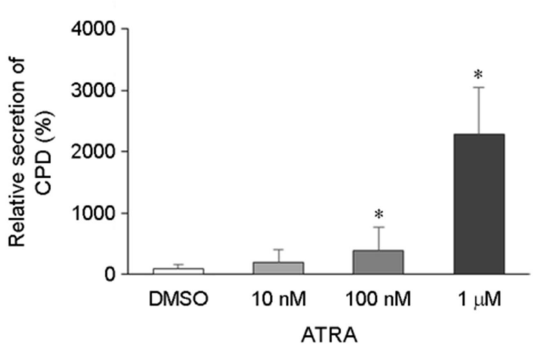

Fig. 4. ATRA induces the secretion of $\mathrm{CPD}$ in a concentration- and time-dependent manner. (A and B) THP-1 cells were treated with $1 \mu \mathrm{M}$ ATRA for $48 \mathrm{~h}$. (C and D) Cells were treated with $1 \mu \mathrm{M}$ ATRA for various time periods, as indicated above. (E and F) Cells were treated with various concentrations of ATRA, as indicated above, for 48 h. (A, C, and E) The culture supernatants were collected, concentrated by filtration, and subjected to western blotting. (B, D, and F) Densitometry analysis of CPD bands shown in (A, C, and E) was performed using a ChemiDoc MP System. Data are presented as mean of relative secretion \pm SD. $* P<0.05$ vs. DMSO.

A

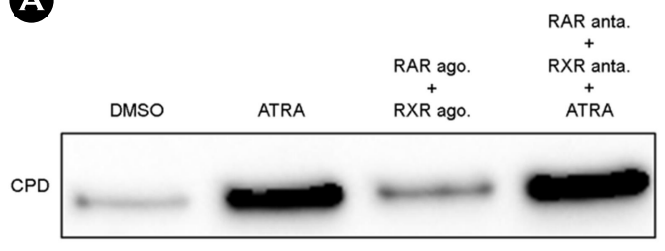

B

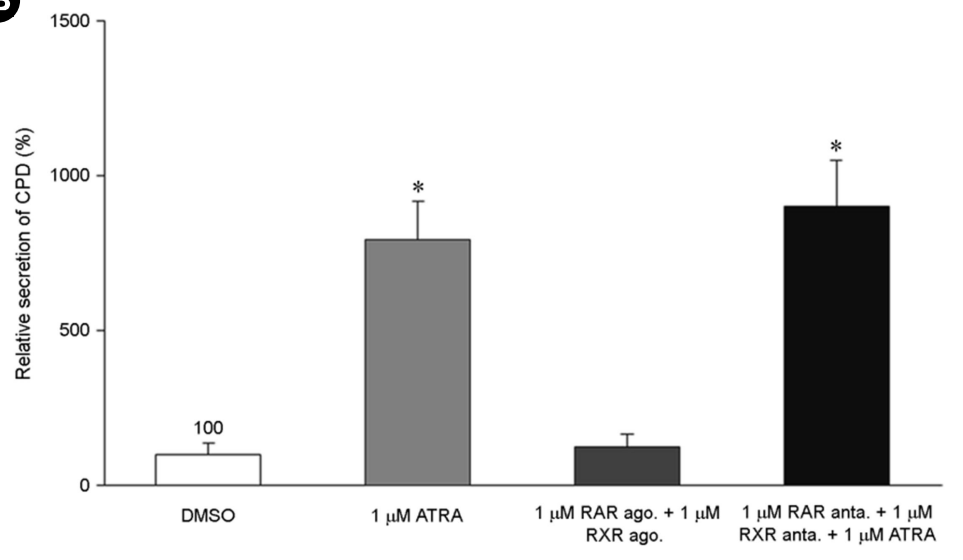

Fig. 5. ATRA induces the secretion of CPD through an RAR/RXR-independent pathway. THP-1 cells were treated with a combinations of $1 \mu \mathrm{M}$ RAR/RXR agonists or with a combination of $1 \mu \mathrm{M}$ RAR/RXR antagonists in the presence of $1 \mu \mathrm{M}$ ATRA for $48 \mathrm{~h}$. (A) The culture supernatants were collected, concentrated by filtration, and subjected to western blotting. (B) Densitometry analysis of CPD bands shown in (A) was performed using a ChemiDoc MP System. Bar graphs present data as mean of relative secretion $\pm \mathrm{SD}$. ${ }^{*} P<0.05$ vs. DMSO. 
mediated by the action of the RAR/RXR heterodimer, we used selective $\mathrm{RAR} \alpha / \mathrm{RXR} \alpha$ agonists and $\mathrm{RAR} \alpha / \mathrm{RXR} \alpha$ antagonists. As shown in Fig. 5, ATRA-induced CPD secretion was not inhibited by pretreatment of THP-1 cells with both the $1 \mu \mathrm{M}$ RAR $\alpha$ antagonist as well as the $\operatorname{RXR} \alpha$ antagonist. Similarly, combined treatment with $1 \mu \mathrm{M}$ RAR $\alpha$ agonist and $1 \mu \mathrm{M}$ RXR $\alpha$ agonist did not induce the secretion of CPD, suggesting that ATRA-induced CPD secretion does not depend on RAR/RXR.

\section{Dexamethasone inhibits ATRA-induced CPD expression and secretion}

Since it has been suggested that CPD is upregulated in macrophages under inflammatory conditions (Hadkar and
A

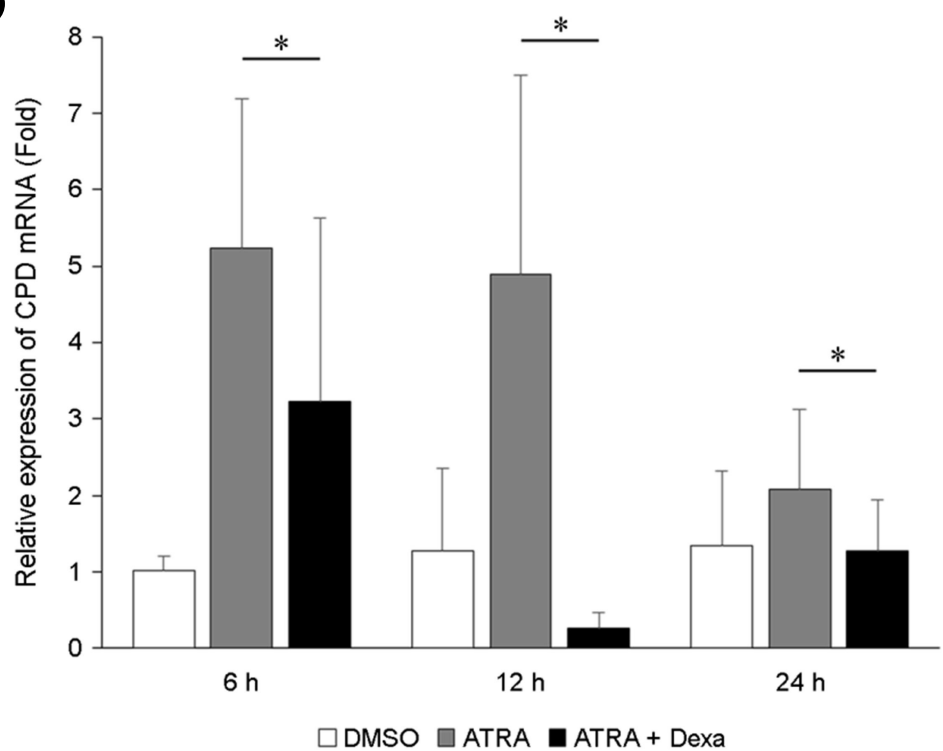

B

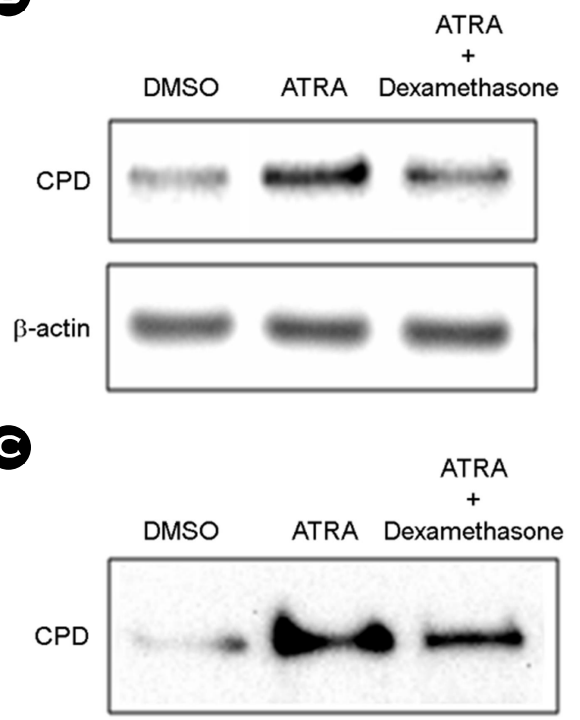

Fig. 6. Dexamethasone inhibits ATRA-induced CPD expression and secretion. (A) THP-1 cells were pretreated with $1 \mu \mathrm{M}$ dexamethasone for $2 \mathrm{~h}$, followed by treatment with $1 \mu \mathrm{M}$ ATRA for different time periods, as indicated above. CPD mRNA expression was measured by qRTPCR. (B) THP-1 cells were pretreated with $1 \mu \mathrm{M}$ dexamethasone for $2 \mathrm{~h}$ and then treated with $1 \mu \mathrm{M}$ ATRA for $48 \mathrm{~h}$. CPD protein expression was analyzed by western blotting. (C) Cells were subjected to the treatment described in (B) and, the culture supernatants were then collected, concentrated by filtration, and subjected to western blotting. Bar graphs present data as mean of relative expression $\pm \mathrm{SD}$. $* P<0.05$.

A

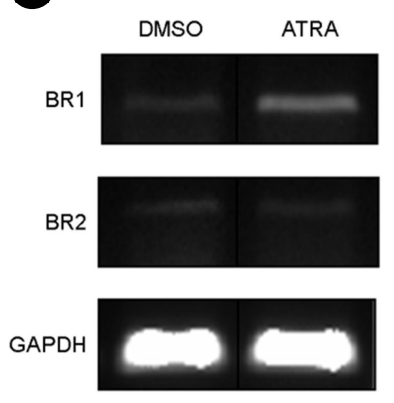

B

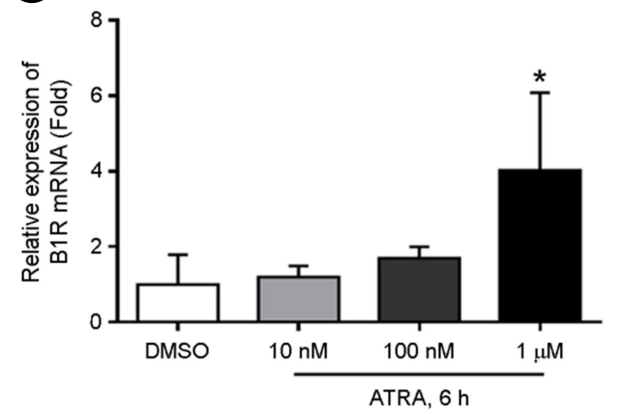

C

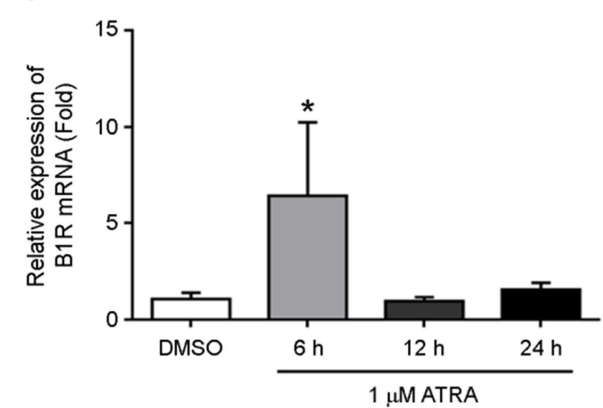

Fig. 7. ATRA induces bradykinin B1 receptor mRNA expression but does not affect bradykinin B2 receptor mRNA expression in THP-1 cells. (A) THP-1 cells were treated with $1 \mu \mathrm{M}$ ATRA for $6 \mathrm{~h}$. The mRNA expression of bradykinin B1 and B2 receptors was examined by semi-quantitative PCR. (B) Cells were treated with different concentrations of ATRA, as indicated, for $6 \mathrm{~h}$. (C) Cells were treated with $1 \mu \mathrm{M}$ ATRA for different time periods, as indicated. Bradykinin B1 receptor mRNA expression was examined by qRT-PCR. Bar graphs present data as mean $\pm \mathrm{SD} . * P<0.05$ vs. DMSO. 
Skidgel, 2001) and our previous study demonstrated that dexamethasone, an anti-inflammatory drug, inhibits ATRAinduced MMP-2 secretion in THP-1 cells (Vu et al., 2018), we tested whether this drug can also suppress ATRA-induced CPD expression and secretion in THP-1 cells. ATRAinduced enhancement of CPD mRNA expression (Fig. 6A), protein expression (Fig. 6B), and secretion (Fig. 6C) were markedly inhibited by a 2 -h pretreatment of THP-1 cells with $1 \mu \mathrm{M}$ dexamethasone.

\section{ATRA induces bradykinin B1 receptor mRNA expres- sion but not $\mathrm{B} 2$ receptor}

Next, we examined effect of ATRA on bradykinin receptor expression in THP-1 cells by qRT-PCR analysis. As shown in Fig. 7A, bradykinin B1 receptor mRNA expression was enhanced by ATRA treatment but B2 receptor expression was not affected. More specifically, $1 \mu \mathrm{M}$ ATRA induced B1 receptor expression, but 10 and $100 \mathrm{nM}$ ATRA did not (Fig. 7B). Moreover, B1 receptor expression was induced at $6 \mathrm{~h}$ and decreased to a basal level by $12 \mathrm{~h}$ after $1 \mu \mathrm{M}$ ATRA treatment (Fig. 7C).

\section{DISCUSSION}

The present study demonstrated that ATRA, but not 9cis-RA, enhanced CPD expression in THP-1 cells. Several previous studies have reported the enhancement of cellular CPD expression by exogenous stimuli. Lipopolysaccharide and IFN- $\gamma$ upregulated CPD expression in murine macrophages and vascular endothelial cells (Hadkar and Skidgel, 2001; Hadkar et al., 2004). Moreover, prolactin, 17 $\beta$-estradiol, and the synthetic androgen R1881 increased CPD expression in breast cancer cells (Abdelmagid and Too, 2008; Koirala et al., 2014), while prolactin and testosterone enhanced CPD expression in prostate cancer cells (Thomas et al., 2012). Interestingly, CPD was downregulated in $\mathrm{CD} 14^{+}$cells isolated from patients with lupus erythematosus, suggesting a possible role for CPD in the pathogenesis of this autoimmune disease (Hoff et al., 2007). All these studies indicate a role of the proteolytic regulation of CPD in immune responses.

In our study, ATRA-induced CPD expression was dependent on the RAR/RXR pathway. Previous studies have shown that the synergistic activation of both partners of the RARRXR complex is necessary to induce ATRA-responsible target gene expression (Brooks et al., 1996; Botling et al., 1997). Similarly, our results revealed that the use of an RAR $\alpha$ agonist moderately induces CPD protein expression, even at higher concentrations, whereas combined treatment with an RAR $\alpha$ agonist and an RXR $\alpha$ agonist significantly induced CPD expression, suggesting that the RAR-RXR complex is required to induce the transcriptional activation of CPD expression. Similar to current observations, our previous study showed that ATRA enhances MMP-2 expression and secretion in THP-1 cells in an RAR/RXR-dependent manner (Vu et al., 2018).

Based on its cellular localization, CPD is thought to play a role in the processing of proteins and peptides within different cellular compartments, such as the secretory compartments, endocytic pathway compartments, and the cell surface (Garcia-Pardo et al., 2017). However, the secretion of CPD from cells has not been reported. In the present study, our results revealed that $\mathrm{CPD}$ secretion does not depend on the RAR/RXR pathway, suggesting a distinct mechanism for CPD secretion. $\mathrm{Ca}^{2+}$ is typically present at millimolar concentrations in the secretory pathway and is necessary to induce rapid membrane fusion to allow for secretion (Jeremic et al., 2004). In our previous study, ATRA increased intracellular calcium levels, and a calcium channel blocker inhibited ATRA-induced MMP-2 secretion in THP-1 cells, suggesting that calcium influx is necessary for ATRA-induced MMP-2 secretion. Another study also showed that ATRA increased intracellular calcium levels (Gao et al., 1998). Based on these reports, we suggest that ATRA-induced calcium influx may be involved in the induction of CPD secretion in THP-1 cells. However, it is necessary to uncover the precise mechanisms of ATRA-induced CPD secretion in THP-1 cells in future studies

In the present study, pretreatment of THP-1 cells with dexamethasone significantly inhibited the ATRA-induced expression and secretion of CPD. Since it is known that ATRA can induce NF- $\mathrm{KB}$ activation in THP-1 cells (Hoang et al., 2019), resulting in CPD expression (Koirala et al., 2014), and that dexamethasone suppresses NF- $\kappa$ B activity in THP-1 cells (Steer et al., 2000), we suggest that the inhibitory 
action of dexamethasone on ATRA-induced CPD expression and secretion may be due to a suppressive effect on NF- $\mathrm{KB}$ activation.

Due to its localization and substrate specificity, it has been proposed that intracellular CPD primarily functions in the maturation of receptors and growth factors (Reznik and Fricker, 2001). However, the function of secreted CPD has not been studied. Several studies have suggested potential substrates of CPD as being soluble immune mediators, such as bradykinin (Timblin et al., 2002) and complement fragments C3a, C4a, and C5a (Skidgel, 1988; Skidgel, 1996). With respect to the former, CPD has been suggested to either inactivate or alter the specificity of the bradikynin by cleaving its C-terminal arginine (Skidgel, 1988). There are two types of receptors for bradykinin on the cell surface: bradykinin B1 and B2 receptors. While the bradykinin B2 receptor is constitutively expressed, the bradykinin B1 receptor is only expressed when cells are stimulated by inflammatory mediators (deBlois et al., 1991; Bhoola et al., 1992). Under normal conditions, bradykinin binds to the bradykinin B2 receptor, whereas cleaved des-arg9-bradykinin, which can be produced from bradykinin by proteolytic removal of the C-terminal arginine, binds to the bradykinin B1 receptor, and acts as an inflammatory mediator, inducing inflammatory responses, such as the enhanced production and release of NO or cytokines (Naffah-Mazzacoratti et al., 2014). Our study revealed that ATRA induces the mRNA expression of the bradykinin $\mathrm{B} 1$ receptor but does not affect $\mathrm{B} 2$ receptor expression in THP-1 cells. Based on our results and those of a previous study (Naffah-Mazzacoratti et al., 2014), we cautiously speculate that CPD activity may play a role in determining the fate of bradykinin-bradykinin receptormediated signaling.

With respect to the complement system, C3a, C4a, and $\mathrm{C} 5 \mathrm{a}$, all have $\mathrm{C}$-terminal arginine residues (Pasupuleti et al., 2007). Monocytes/macrophages express both the C3a receptor $(\mathrm{C} 3 \mathrm{aR})$ and $\mathrm{C} 5 \mathrm{aR}$ to bind their respective ligands C3a and C5a (Stephan et al., 2012). Previous structural studies have proposed that the C-termini of C3a ( $\mathrm{Lu}$ et al., 1984) and C5a (Huber-Lang et al., 2003) contribute to their binding to their corresponding receptors. Thus, proteolytic cleavage of the $\mathrm{C}$-terminal arginines of both $\mathrm{C} 3 \mathrm{a}$ and $\mathrm{C} 5 \mathrm{a}$ by cell surface or secreted CPD may play a critical role in the regulation of $\mathrm{C} 3 \mathrm{a}(5 \mathrm{a})-\mathrm{C} 3 \mathrm{a}(5 \mathrm{a})$ receptor interactions. Based on the essential role of ATRA in immune regulation as well as previous studies showing inflammatory stimuliinduced CPD expression (Hadkar and Skidgel, 2001; Hadkar et al., 2004), we suggest that ATRA-induced CPD secretion may be involved in the regulation of inflammatory responses by cleavage of inflammatory mediators, such as $\mathrm{C} 3 \mathrm{a}, \mathrm{C} 5 \mathrm{a}$, and/or bradykinin. To test this hypothesis, it is necessary to examine whether the ATRA-induced secretion of CPD cleaves the substrates mentioned above in a future study.

In summary, this study revealed, for the first time, that ATRA enhances CPD expression in THP-1 cells in an RAR /RXR-dependent manner and CPD secretion in a RAR/ RXR-independent manner. This enhanced expression and secretion of CPD were inhibited by dexamethasone treatment. We suggest that increased expression and secretion of CPD induced by ATRA treatment may be involved in regulating inflammatory responses.

\section{ACKNOWLEDGEMENT}

This research was supported by Basic Science Research Program through the National Research Foundation of Korea (NRF) funded by the Ministry of Education (NRF2018R1D1A1A09083908).

\section{CONFLICT OF INTEREST}

The authors declare that they have no competing interests.

\section{REFERENCES}

Abdelmagid SA, Too CK. Prolactin and estrogen up-regulate carboxypeptidase-d to promote nitric oxide production and survival of mcf-7 breast cancer cells. Endocrinology. 2008. 149: 4821-4828.

Bastien J, Rochette-Egly C. Nuclear retinoid receptors and the transcription of retinoid-target genes. Gene. 2004. 328: 1-16.

Bhoola KD, Figueroa CD, Worthy K. Bioregulation of kinins: kallikreins, kininogens, and kininases. Pharmacol Rev. 1992. 44: $1-80$.

Botling J, Castro DS, Oberg F, et al. Retinoic acid receptor/ retinoid $\mathrm{X}$ receptor heterodimers can be activated through both subunits providing a basis for synergistic transactivation and 
cellular differentiation. J Biol Chem. 1997. 272: 9443-9449.

Brooks SC $3^{\text {rd }}$, Kazmer S, Levin AA, et al. Myeloid differentiation and retinoblastoma phosphorylation changes in HL-60 cells induced by retinoic acid receptor- and retinoid X receptorselective retinoic acid analogs. Blood. 1996. 87: 227-237.

deBlois D, Bouthillier J, Marceau F. Pulse exposure to protein synthesis inhibitors enhances vascular responses to des-Arg9bradykinin: possible role of interleukin-1. Br J Pharmacol. 1991. 103: 1057-1066.

DePaolo RW, Abadie V, Tang F, et al. Co-adjuvant effects of retinoic acid and IL-15 induce inflammatory immunity to dietary antigens. Nature. 2011. 471: 220-224.

Elias KM, Laurence A, Davidson TS. Retinoic acid inhibits Th17 polarization and enhances FoxP3 expression through a Stat-3/ Stat-5 independent signaling pathway. Blood. 2008. 111: 1013 -1020 .

Eriksen AB, Berge T, Gustavsen MW, et al. Retinoic acid enhances the levels of IL-10 in TLR-stimulated B cells from patients with relapsing-remitting multiple sclerosis. J Neuroimmunol. 2015. 278: 11-18.

Gao ZY, Xu G, Stwora-Wojczyk MM, et al. Retinoic acid induction of calcium channel expression in human NT2N neurons. Biochem Biophys Res Commun. 1998. 247: 407-413.

Garcia-Pardo J, Tanco S, Diaz L, et al. Substrate specificity of human metallocarboxypeptidase D: Comparison of the two active carboxypeptidase domains. PLoS One. 2017. 12: e0187778.

Gundra UM, Girgis NM, Gonzalez MA, et al. Vitamin A mediates conversion of monocyte-derived macrophages into tissueresident macrophages during alternative activation. Nature Immunology. 2017. 18: 642-653.

Hadkar V, Sangsree S, Vogel SM, et al. Carboxypeptidase-mediated enhancement of nitric oxide production in rat lungs and microvascular endothelial cells. Am J Physiol Lung Cell Mol Physiol. 2004. 287: L35-L45.

Hadkar V, Skidgel RA. Carboxypeptidase D is up-regulated in raw 264.7 macrophages and stimulates nitric oxide synthesis by cells in arginine-free medium. Mol Pharmacol. 2001. 59: 1324 -1332 .

Hall, JA, Cannons JL, Grainger JR, et al. Essential role for retinoic acid in the promotion of $\mathrm{CD} 4(+) \mathrm{T}$ cell effector responses via retinoic acid receptor alpha. Immunity. 2011. 34: 435-447.

Ho VW, Hofs E, Elisia I, et al. All trans retinoic acid, transforming growth factor $\beta$ and prostaglandin E2 in mouse plasma synergize with basophil-secreted interleukin-4 to M2 polarize murine macrophages. PLoS One. 2016. 11: article e0168072.

Hoang TX, Jung JH, Kim JY. All-trans retinoic acid enhances bacterial flagellin-stimulated proinflammatory responses in human monocyte THP-1 cells by upregulating CD14. BioMed Res Int. 2019. 2019: article ID 8059312.

Hoff NP, Degrandi D, Hengge U, et al. Carboxypeptidase D: a novel TGF-beta target gene dysregulated in patients with lupus erythematosus. J Clin Immunol. 2007. 27: 568-579.

Huber-Lang MS, Sarma JV, McGuire SR, et al. Structure-function relationships of human C5a and C5aR. J Immunol. 2003. 170: 6115-6124.

Iwata M, Hirakiyama A, Eshima Y, et al. Retinoic acid imprints guthoming specificity on T cells. Immunity. 2004. 21: 527-538.

Jeremic A, Kelly M, Cho JA, et al. Calcium drives fusion of SNARE-apposed bilayers. Cell Biol Int. 2004. 28: 19-31.

Kalinina E, Varlamov O, Fricker LD. Analysis of the carboxypeptidase D cytoplasmic domain: Implications in intracellular trafficking. J Cell Biochem. 2002. 85: 101-111.

Kang BY, Chung SW, Kim SH, et al. Retinoid-mediated inhibition of interleukin-12 production in mouse macrophages suppresses Th1 cytokine profile in CD4(+) T cells. Brit J Pharmacol. 2000. 130: 581-586.

Kim $\mathrm{CH}$. Control of innate and adaptive lymphocytes by the RAR-retinoic acid axis. Immune Netw. 2018. 18: e1.

Klebanoff CA, Spencer SP, Torabi-Parizi P, et al. Retinoic acid controls the homeostasis of pre-cDC-derived splenic and intestinal dendritic cells. J Exp Med. 2013. 210: 1961-1976.

Koirala S, Thomas LN, Too CK. Prolactin/Stat5 and androgen R1881 coactivate carboxypeptidase-D gene in breast cancer cells. Mol Endocrinol. 2014. 28: 331-343.

Lu ZX, Fok KF, Erickson BW, et al. Conformational analysis of $\mathrm{COOH}$-terminal segments of human $\mathrm{C} 3 \mathrm{a}$. Evidence of ordered conformation in an active 21-residue peptide. J Biol Chem. 1984. 259: 7367-7370

Manoury B. Proteases: essential actors in processing antigens and intracellular toll-like receptors. Front Immunol. 2013. 4: 299.

Marshall NC, Finlay BB, Overall CM. Sharpening host defenses during infection: proteases cut to the chase. Mol Cell Proteomics. 2017. 16: S161-S171.

Mehta K, McQueen T, Tucker S, et al. Inhibition by all-transretinoic acid of tumor necrosis factor and nitric oxide production by peritoneal macrophages. J Leuk Biol. 1994. 55: 336-342.

Mielke LA, Jones SA, Raverdeau M, et al. Retinoic acid expression associates with enhanced IL-22 production by gammadelta $\mathrm{T}$ 
cells and innate lymphoid cells and attenuation of intestinal inflammation. J Exp Med. 2013. 210: 1117-1124.

Naffah-Mazzacoratti Mda G, Gouveia TL, Simoes PS, et al. What have we learned about the kallikrein-kinin and reninangiotensin systems in neurological disorders? World J Biol Chem. 2014. 5: 130-140.

Niederreither K, Dolle P. Retinoic acid in development: towards an integrated view. Nat Rev Genet. 2008. 9: 541-553.

Parks WC, Wilson CL, López-Boado YS. Matrix metalloproteinases as modulators of inflammation and innate immunity. Nat Rev Immunol. 2004. 4: 617-629.

Pasupuleti M, Walse B, Nordahl EA, et al. Preservation of antimicrobial properties of complement peptide $\mathrm{C} 3 \mathrm{a}$, from invertebrates to humans. J Biol Chem. 2007. 282: 2520-2528.

Reznik SE, Fricker LD. Carboxypeptidases from A to Z: implications in embryonic development and Wnt binding. Cell Mol Life Sci. 2001. 58: 1790-1804.

Scheffel F, Heine G, Henz BM, et al. Retinoic acid inhibits CD40 plus IL-4 mediated IgE production through alterations of sCD23, sCD54 and IL-6 production. Inflamm Res. 2005. 54: 113-118.

Sim RB, Laich A. Serine proteases of the complement system. Biochem Soc Trans. 2000. 28: 545-550.

Skidgel RA, Erdos EG. Cellular carboxypeptidases. Immunol Rev. 1998. 161: 129-141.

Skidgel RA. Basic carboxypeptidases: regulators of peptide hormone activity. Trends Pharmacol Sci. 1988. 9: 299-304.

Skidgel RA. Structure and function of mammalian zinc carboxypeptidases. In zinc metalloproteases in health and disease. CRC Press. 1996. 261-304.

Steer JH, Kroeger KM, Abraham LJ, et al. Glucocorticoids suppress tumor necrosis factor-alpha expression by human monocytic THP-1 cells by suppressing transactivation through adjacent NF-kappa B and c-Jun-activating transcription factor-2 binding sites in the promoter. J Biol Chem. 2000. 275: 18432-18440.
Stephan AH, Barres BA, Stevens B. The complement system: an unexpected role in synaptic pruning during development and disease. Annu Rev Neurosci. 2012. 35: 369-389.

Thomas LN, Morehouse TJ, Too CK. Testosterone and prolactin increase carboxypeptidase-D and nitric oxide levels to promote survival of prostate cancer cells. Prostate. 2012. 72: 450-460.

Timblin B, Rehli M, Skidgel RA. Structural characterization of the human carboxypeptidase D gene and its promoter. Int Immunopharmacol. 2002. 2: 1907-1917.

Tsai MJ, O'Malley BW. Molecular mechanisms of action of steroid /thyroid receptor superfamily members. Annu Rev Biochem. 1994. 63: 451-486.

Varlamov O, Eng FJ, Novikova EG, et al. Localization of metallocarboxypeptidase D in AtT-20 cells. Potential role in prohormone processing. J Biol Chem. 1999. 274: 14759-14767.

Varlamov O, Fricker LD. Intracellular trafficking of metallocarboxypeptidase D in AtT-20 cells: localization to the transGolgi network and recycling from the cell surface. J Cell Sci. 1998. 111: 877-885.

Vu HT, Hoang TX, Kim JY. All-trans retinoic acid enhances matrix metalloproteinase 2 expression and secretion in human myeloid leukemia THP-1 cells. Biomed Res Int. 2018. 2018: article ID 5971080

Wang X, Allen C, Ballow M. Retinoic acid enhances the production of IL-10 while reducing the synthesis of IL-12 and TNF- $\alpha$ from LPS-stimulated monocytes/macrophages. J Clin Immunol. 2007. 27: 193-200.

https://doi.org/10.15616/BSL.2020.26.4.256

Cite this article as: Nguyen HTT, Kim JY. All-trans Retinoic Acid Induces Expression and Secretion of Carboxypeptidase D in THP-1 Cells. Biomedical Science Letters. 2020. 26: 256-266. 